\title{
Morphology, Anatomy, Palynology and Seed Micromorphology of Libyan Endemic Bellis Sylvestrisvar. Cyrenaica (Asteraceae)
}

\author{
Ghalia T. El Rabiae*, Seham H. Elbadry \\ Department of Botany, Faculty of Science, Benghazi University, Libya
}

*Corresponding Author: Ghalia T. El Rabiae, Department of Botany, Faculty of Science, Benghazi University, Libya

\begin{abstract}
Bellis L. Belonging to the family Asteraceae and has been included in subtribe Asterinae (tribe Astereae). In the present work, the morphological characters, stem, petiole and leaf anatomy, pollen micromorphology of Endemic Bellis sylvestrisvar. cyrenaicafrom Libya have been investigated on light and scanning electron microscope. Bellis sylvestrisvar. cyrenaicais an endemic species from Libya and limited information about the native taxon. All morphological, anatomical and palynological characteristics are firstly determined in this study. Palynology study showed that pollen characters were found medium size, oblate spheroidal, tricolporate and echinate ornamentation of the studied taxon. Seed micromorphological features were also given
\end{abstract}

Keywords: Endemic Bellis sylvestrisvarcyrenaica., Asteraceae, Morphology, Anatomy, Palynology,Libya.

\section{INTRODUCTION}

Bellis L. popularly is known as Daisy flower belonging to the family Asteraceae and has been included in subtribe Asterinae -tribe Astereae (Bremer, 1994). This genus also known as a traditional wound herb (Ai- Douri and Al-Essa 2010) and it was used for the treatment of bruises, broken bones and wounds (Mitich 1997). It has also been used in traditional folk medicine for the treatment of sore throat (Uysalet al. 2010) headache, common cold, eczema, wound healing, diarrhea, peptic ulcer, gastritis, rheumatism, asthma, hemorrhoids and as a vulnerary expectorant and laxative (kavalciogluet al. 2010, karakas et al. 2012, Melikoğlu 2015). Bellis L. isrepresented

15 species on Europe and Mediterranean region which is the largest center of diversity of the genus but is commonly found as invasive plant in North America (Webb 1976).

The previous studies reported that pollen and seed micromorphologies are efficient in the systematics of the Asteraceae family (Shabestariet al. 2013, Frangiote-Pallone and De Souza 2014). Akyalçinet al. (2011) studied the pollen morphology of six AchilleaL. species and their results show that the pollen grains were oblate- spheroidal, prolate, sub-prolate and generally tricolporate, though at times tetracolporate or even pentacolporate. Joujehet al. (2019) reported that the pollen grains of Centaurea from Syria were similar in shape, size, aperture characters and symmetry, while they differ in color, exine ornamentation pattern and density of the spines. Karahan (2020) found that the pollen grains Some morphological and anatomical studies of the Asteraceae family have been carried out. Metcalfe and Chalk (1950) reported that due to the diversity of their habitats, Asteraceae species show various anatomical differentiations, especially in the structures of leaves.Fahn (1979) observed that secretory structures have an important diagnostic value in Asteraceae. These secretory structures such as ducts, cavities, idioblasts, laticifers, hydathodes, extrafloralnectaries and trichomes presented diagnosis value at genus level (Castro et al. 1997). It has been suggested that trichome micromorphology was useful in the systematics of Asteraceae (Ciccarelliet al. 2007). Napp-Zinn and Eble (1978) carried out a detailed ultrastructure study of the glandular and nonglandular hairs of twenty genera of the Anthemidae. Glandular hairs in Asteraceae may be widely distributed both on the vegetative and the floral parts (Ciccarelli et al. 2007).

Karahan (2020) studied the leaf anatomy of Bellis and showed that the upper and lower epidermis consist of uniseriate cells with different sizes and shapes. Also he found that the mesophyll of $B$. annuaand $B$. perenniswas unifacial, while the mesophyll of $B$. sylvestriswas bifacial. In his study of the stem he found that the epidermis consists of 1-2 layered of oval cells. 
In Libya, according to the Flora of Libya the genus Bellis is represented by three taxa with two species and one endemic variety (Jafri, 1983). B. sylvestrisvar. cyrenaicais endemic variety collected from Cyrenaica which is located in the Northeast of Libya. This taxon is a very distinctive but there is limited information about it.

B. sylvestrisvar. cyrenaica, the object of the present study is endemic plant in Libya look like $B$. sylvestrisvar. sylvestrisfrom which differ by its leaves and peduncle. The present study aims to give as a first detailed account of the morphological, anatomical and palynological characteristics of $B$. sylvestrisvar. cyrenaicato variety whether these data can be important from the taxonomic point of view (no study about the anatomy, palynology and micromorphology of B. sylvestrisvar. cyrenaicaappear to be carried out untilnow.

\section{MATERIALS AND METHODS}

Five specimens were collected of B. sylvestrisvar. cyrenaicaduring their flowering and fruiting time, between 2017 and 2019. The research area was given in Fig. 1 according to Davis's Grid system (Davis 1965-1985). Specimens were dried according to standard herbarium techniques and are deposited in the Herbarium of Cyrenaica Herbarium $(\mathrm{CH})$ at the Botany Department, Sciences faculty, Benghazi University). The plant samples were preserved in $70 \%$ ethanol for anatomical analysis. Transverse sections of stem, petiole and leaf samples were prepared. Slides were observed with light microscope. For anatomical description, the terminology of Metcalfe and Chalk (1957) was used. Pollen grains were obtained from mature anthers of dried flowers and measured under a light microscope. The measurements of the polar axis $(\mathrm{P})$, the equatorial diameter $(\mathrm{E})$, the ornamentation, the number of apertures, the aperture type, the spine length, the spine width for 10 pollen grains were conducted under light microscope. The terms used for describing the Seed surface patterns have been adopted according to Koulet al. (2000). All photographs were taken at Central Laboratory of Alexandria University,Egypt.

\section{RESULTS}

\subsection{Morphological Characters}

B. sylvestrisvar. cyrenaicaBéguinot in Atti Accad. Ven. Trent. Istr. 9:25.1916.

Type: Described from Libya: Cyrenaica

B. sylvestrisvar. cyrenaicais perennial rosette herb, $4-18 \mathrm{~cm}$ long, with glaucous colored covered with density hairs (Fig. 1). Stems are short rhizomes, covered by hairs. The leaves are spathulate, $4-10 \mathrm{~cm}$ in length, exstipulate, petiolate up to $3 \mathrm{~cm}$ petiole, sinuate-dentate with obtuse apex, covered with glandular and non-glandular trichomes. Stems bearing one peduncule. Peduncule are monocephalic, slender and 2- $10 \mathrm{~cm}$ long. Involucre 22-27 arranged in two rows, lanceolate. Ray flowers ligules white with purplish tinge, 8-14 mm long. Disc corollas 2.5x1-1.5 mm long and yellow (Fig 1). Cypsela, brown, elongated oval shape, $1.8-2 \mathrm{~mm}$ long and 0.6-0.8 $\mathrm{mm}$ wide, quite strongly pubescent.

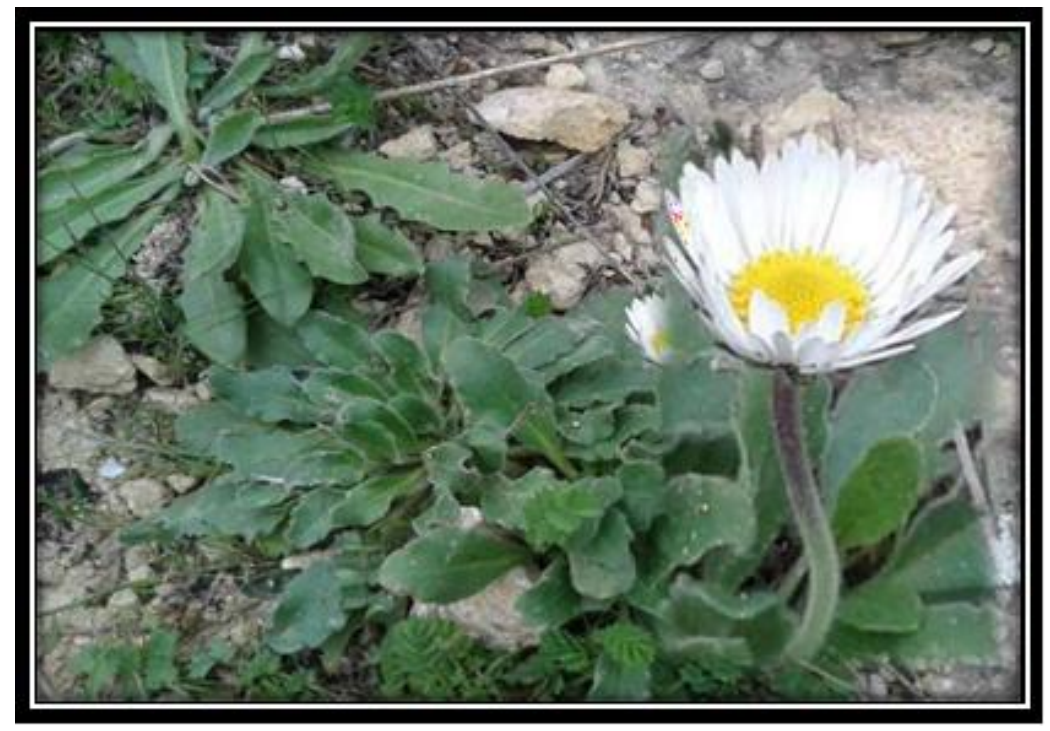

Fig1. General morphology of Bellis sylvestrisvar. cyrenaica 
Morphology, Anatomy, Palynology and Seed Micromorphology of Libyan Endemic Bellis Sylvestrisvar. Cyrenaica (Asteraceae)

\subsection{Pollen Morphology}

Under light microscope, the pollen grains are isopolar, radially symmetrical and prolate-spheroidal. Their apertures are tricolporate; The ornamentation is echinate in the studied taxon. The spine base is determined as circular-elliptic to circular. The polar axis $(\mathrm{P})$ ranged from 22-25 $\mu \mathrm{m}(23.5) \mu \mathrm{m}$ and equatorial axis (E) ranged from $22-23 \mu \mathrm{m}(22.5) \mu \mathrm{m}$. The spine lengths ranged from $1.7 \mu \mathrm{m}$ to $2.3 \mu \mathrm{m}$ and the spine widths ranged from $1.2 \mu \mathrm{m}$ to $1.95 \mu \mathrm{m}$. Under scanning electron microscope, the distance between spines ranged from $1.17 \mu \mathrm{m}$ to $2 \mu \mathrm{m}$ (Fig. 2).

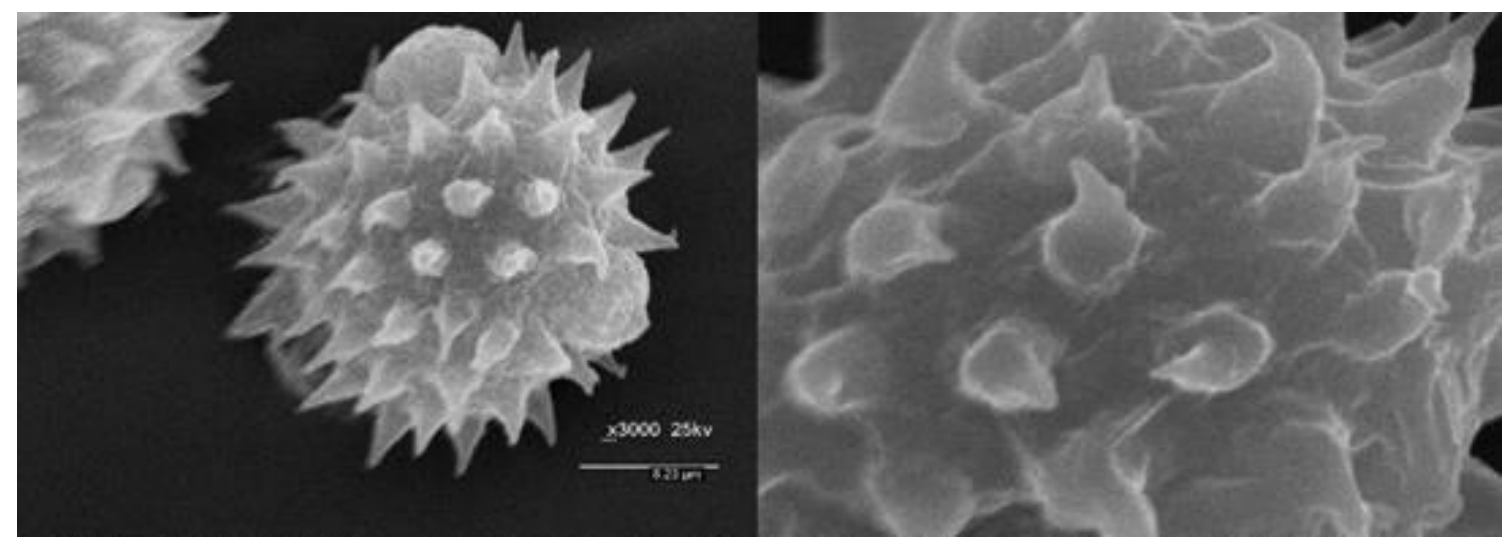

Fig.2. Scanning electron micrographs (SEM) of pollen grains of B. sylvestrisvar. cyrenaica.

\subsection{Seed Morphology}

Seeds have ovate shape with reddish brown color. The size of seeds was $0.5-0.7$ x $0.2-0.4 \mathrm{~mm}$. The seed coat ornamentation is reticulate (Figure $3 \mathrm{~A}, \mathrm{~B}$ ).

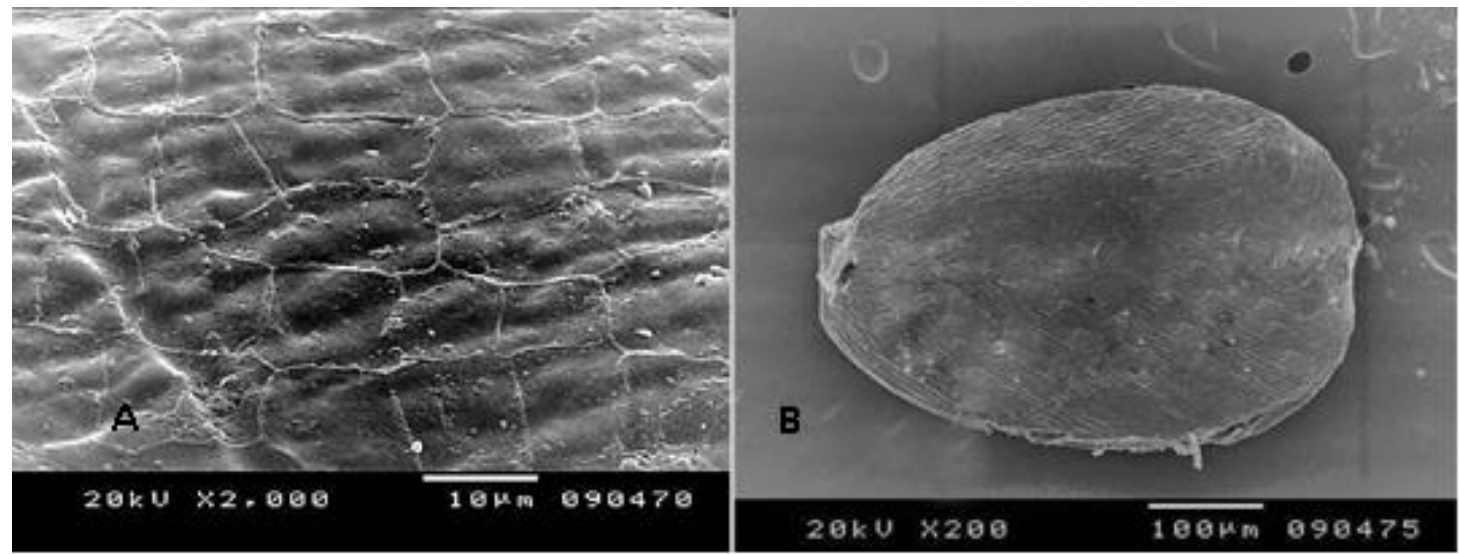

Fig.3. Scanning electron micrographs (SEM) of the seed. A-General appearance; B-Surface ornamentation of B. sylvestrisvar. cyrenaica.

\subsection{Anatomical Characters}

Stem: The transverse section of the stem, the epidermis consists of 2-5 layered lignified irregular cells. There were eglandular hairs on the epidermis. Under the epidermis, the cortex contains multi layers of different sized and shaped parenchyma cells. The cortex cells rich by starch and organic material and ends with endodermis layer. The vascular system was of open collateral type. The pith was wide and composed of polygonal or oval parenchymatous cells (Fig. 4A, B).

Leaves: The transverse section of the leaf of studied taxon showed that the upper and lower epidermis composed of uniseriate cells with different sizes and shapes covered by thin cuticle. There were nonglandular multicellular, uniseriate hairs on both sides and anomocytic stomata. Mesophyll tissue was differentiated as palisade and spongy parenchyma cells. Under the upper epidermis, the mesophyll contains 3-4 layers of palisade parenchyma and 3-5 layers of spongy parenchyma. The vascular bundle was located solely in the parenchymal tissue in the middle vessel region. The xylem arranged in straight line in a single layer and face towards the upper surface, while the phloem faces the lower epidermis. (Fig. 4B-C). 
Peduncle: Peduncle cross-section was Elongated carousel in shape. The epidermis was composed of one layer of different sized cells, with thickened outer walls and were covered with non-glandular, multicellular uniseriate hairs. Epidermis was followed by collenchymatous hypodermis and parenchymatous cortex. In the central cylinder 12- 13 of collateral and open vascular bundles were arranged in a circle followed by hollow parenchymatous pith (Fig. 4 D).

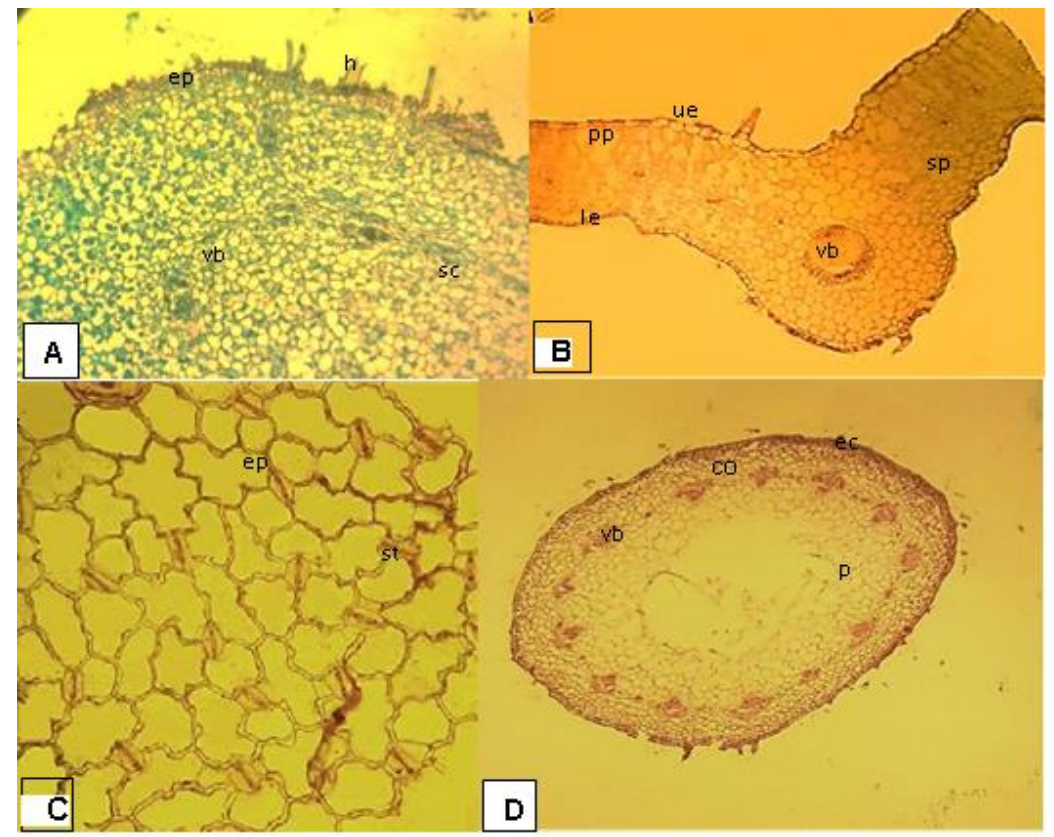

Fig.4. Light microphotographs of the transverse sections of Bellis sylvestrisvar. cyrenaica: A. Stem, B. Leaf, C. Stomata D. Peduncle; co-cortex, ep-epidermis, le-lower epidermis, p-pith, pp-palisade parenchyma, sc-storage cells, sp-spongy parenchyma, ue- upper epidermis, vb-vascular bundle.

\section{DISCUSSION}

From searching literature, it is clear that no study to date has examined endemic Bellis sylvestrisvar. cyrenaicaexcept general taxonomic properties of the taxon. The morphological properties of investigated taxon were in agreement with the description of the plant in Flora of Libya. The anatomical characters of the studied plant are reported for the first time in the present study. The findings of Bellis sylvestrisvar. cyrenaicawere compared with anatomical studies made on the genus Bellis in literatures. The results of palynological study showed that the palynological characters obtained were generally similar to the results of Akyalçinet al. (2011).

\section{REFERENCES}

[1]Ai-Douri, N.A., Al-Essa, L.Y., 2010: A survey of plants used in Iraqi traditional medicine. Jordan Journal of Pharmaceuti-cal Sciences 3, 100-108.

[2]Akçin T.A., Akçin, A., 2010: Morphological and anatomical char-acteristics and taxonomical significance of achene micro-morphology of Achilleaphrygia and A. gypsicola (Asterace-ae), endemic to Turkey. Nordic Journal of Botany 28, 65-73.

[3]Akyalçin, H., Arabaci, T., Yildiz, B., 2011: Pollen morphology of six Achillea L. sect. Achillea (Asteraceae) species in Turkey. Turkish Journal of Botany 35, 183-201.

[4]Avci, M., 1996: The floristic regions of Turkey and a geographical approach for Anatolian Diagonal. Review of the Department of Geography University of Istanbul 3, 59-91

[5]Bremer, K., 1994: Bellis L. In: Bremer, K., Anderberg, A.A (eds.), Asteraceae, cladistics and classification, 202-233. Timber Press, Oregon.

[6]Calvo, J., Quintanar, A., Aedo, C., 2012: Typification of four spe-cies names of Bellis (Compositae). Nordic Journal of Botany 30, 668-670.

[7]Castro, M. M., Leitão-Filho, H. F., Monteiro, W. R., 1997: Utiliza-ção de estruturassecretorasnaidentificação dos gêneros de Asteraceaedeumavegetação de cerrado. RevistaBrasileria De Biologia 20, 163-174.

[8]Ciccarelli, D., Garbari F., Pagni, A. M., 2007: Glandular hairs of theovary: a helpful character for Asteroideae (Asteraceae) taxon-omy? AnnalesBotaniciFennici 44, 1-7. Davis, P.H., 1965-1985: Flora of Turkey and The 
East Aegean Is-land, vol. 1-9. Edinburgh University Press, Edinburgh.

[9]Fahn, A., 1979: Secretory Tissues in Plants. Academic Press, London.

[10] Frangiote-Pallone, S., De Souza, L.A., 2014: Pappus and cypsela ontogeny in Asteraceae: Structural considerations of the tribal category. Revista Mexicana de Biodiversidad 85, 62-77.

[11] Jafri, S. M, A. El Gadi. 1983: (Asteraceae) Flora of Libya. Al Faateh Univ. Tripoli. 107:1, 21

[12] Joujeh, R., Zaid, S. and Mona, S. 2019: Pollen morphology of some selected species of the genus CentaureaL. (Asteraceae) from Syria. South African Journal of Botany, 125, 196-201.

[13] Karahan, F. 2020: Morphology, anatomy, palynology and achene micromorphology of Bellis L. (Asteraceae) species from Turkey. Acta Bot. Croat. 79(1),59-67.

[14] Karakaş, F.P., Karakaş, A., Boran, Ç., Türker, A.U., Yalçin, F.N., Bilensoy, E., 2012: The evaluation of topical administration of Bellis perennis fraction on circular excision woundhealing in Wistar albino rats. Pharmaceutical Biology 50, 1031-1037. Kavalcioğlu, N., Açik, L., Pinar, M., 2010: Comparative RAPD analysis and pollen structure studies of Bellis perennisL. Turk-ish Journal of Botany 34,479-484.

[15] Koul, K.K., Nagpal, R. and Raina, S.N. 2000: Seed coat microsculpturing in Brassica and allied genera (Subtribe Brassicinae, Raphaninae, Moricandiinae). Ann. Bot. 86: 385-397.

[16] Melikoğlu, G., 2015: The plants traditionally used to treatment of asthma in Turkey. Marmara Pharmaceutcal Journal 19, 1-11 (in Turkish).

[17] Metcalfe, C. R., Chalk, L., 1950: Anatomy of the dicotyledons: leaves, stem, and wood in relation to taxonomy with notes on economic uses. vol. 2, Claredon Press, Oxford.

[18] Metcalfe,C.R., Chalk, L., 1957: Anatomy of the dicotyledons I. Clarendon Press, London.

[19] Mitich, L.W., 1997: English daisy (Bellis perennisL.). Weed Tech-nology 11, 626- 628.

[20]Napp-Zinn, K., Eble., M., 1978: BeiträgezursystematischenAnatomie der Anthemideae: die Spaltöffnungsapparate. Plant Systematics and Evolution 130, 167- 190.

[21] Shabestari, E.S.B., Attar, F., Riahi, H., Sheidai, M., 2013: Pollen morphology of Centaurea L. (Asteraceae) in Iran. Acta Bo-tanicaBrasilica 27, 669-679.

[22]Uysal, I., Onar, S., Karabacak, E., Çelik, S., 2010: Ethnobotanical aspects of Kapıdağ Peninsula (Turkey). Biological Diversity and Conservation 3, 15-22.

[23] Webb, D.A., 1976: Bellis L. and Bellium L. In: Tutin, T.G., Burges, N.A., Charter, A.O., Edmonson, J.R., Heywood, V.H., Moore, D.M., Valentine, D.H.,Walters, S.M.,Webb, D.A. (eds.), Flora Europaea 4, 111112. Cambridge University Press, Cambridge.

Citation: Ghalia T. El Rabiae, Seham H. Elbadry, (2020). “Morphology, Anatomy, Palynology and Seed Micromorphology of Libyan Endemic Bellis Sylvestrisvar. Cyrenaica (Asteraceae). International Journal of Advanced Research in Botany (IJARB), 6(1), pp.25-29. DOI: http://doi.org/10.20431/2455-4316.0601004

Copyright: (C) 2020 Authors, This is an open-access article distributed under the terms of the Creative Commons Attribution License, which permits unrestricted use, distribution, and reproduction in any medium, provided the original author and source are credited. 